\title{
The enhanced expression of the matrix metalloproteinase 9 in nasal NK/T-cell lymphoma
}

\author{
Koh-ichi Sakata*1, Masanori Someya ${ }^{1}$, Mutsuko Omatsu ${ }^{2}$, Hiroko Asanuma ${ }^{2}$, \\ Tadashi Hasegawa ${ }^{2}$, Masato Hareyama ${ }^{1}$ and Tetsuo Himi ${ }^{3}$
}

Address: ${ }^{1}$ Department of Radiology, Sapporo Medical University, School of Medicine, Sapporo, Japan, ${ }^{2}$ Department of Surgical Pathology, Sapporo Medical University, School of Medicine, Sapporo, Japan and ${ }^{3}$ Department of Otorhinolaryngology, Sapporo Medical University, School of Medicine, Sapporo, Japan

Email: Koh-ichi Sakata* - sakatako@sapmed.ac.jp; Masanori Someya - someya@sapmed.ac.jp; Mutsuko Omatsu - m.omatsu@sapmed.ac.jp; Hiroko Asanuma - asanuma@sapmed.ac.jp; Tadashi Hasegawa - hasetada@sapmed.ac.jp; Masato Hareyama - Hareyama@sapmed.ac.jp;

Tetsuo Himi - himi@sapmed.ac.jp

* Corresponding author

Published: 19 December 2007

BMC Cancer 2007, 7:229 doi:10.1 186/147|-2407-7-229
Received: 5 June 2007

Accepted: 19 December 2007

This article is available from: http://www.biomedcentral.com//47/-2407/7/229

(C) 2007 Sakata et al; licensee BioMed Central Ltd.

This is an Open Access article distributed under the terms of the Creative Commons Attribution License (http://creativecommons.org/licenses/by/2.0), which permits unrestricted use, distribution, and reproduction in any medium, provided the original work is properly cited.

\begin{abstract}
Background: Nasal NK/T cell lymphoma is an aggressive disease and has a poor prognosis. Nasal NK/T cell lymphoma is refractory to conventional chemotherapy and has strong tendency of widespread relapse or dissemination into distant sites.

Methods: We immunohistochemically studied nasal NK/T-cell lymphoma to elucidate the unique characteristics of nasal NK/T-cell lymphoma, such as its higher metastatic tendency and its vast necrosis which leads to destruction of the involved tissues. The expression of P-glycoprotein and MMP-9 was evaluated in the 20 patients with nasal NK/T-cell lymphoma and 25 with nasal non-NK/T-cell lymphoma and the relationship between expression of these proteins and clinical results were analyzed in this report.

Results: Overall 5-year survival rates for patients with nasal NK/T cell lymphoma, and nasal non-NK/T cell lymphoma were $51 \%$, and $84 \%$. Distant involvement free 5 -year survival rates for patients with nasal NK/T cell lymphoma, and nasal non-NK/T cell lymphoma were $53 \%$, and $79 \%$.

Overall positivity for P-glycoprotein was observed in 10 of 19 patients with NTL and in 13 of 23 patients with non-NTL. When the overall survival rate was compared between patients with P-glycoprotein positive and negative, there was no difference between them.

Sixteen of the 19 patients with nasal NK/T cell lymphoma expressed MMP-9. In contrast, only 8 of the 22 patients with nasal non-NK/T cell lymphoma expressed MMP-9. Distant involvement free 5-year survival rates for patients with MMP-9 negative, and MMP-9 positive were $92 \%$, and $61 \%$, respectively. The difference was statistically significant $(p=0.027)$.

Conclusion: Positive immunoreactivity for P-glycoprotein was not an independent prognostic factor in nasal NK/T-cell lymphomas, which stresses the importance of exploring other mechanisms of drug resistance. The strong expression of MMP-9 is uniquely characteristic of nasal NK/T cell lymphoma and may contribute to its strong tendency to disseminatate and the extensive necrosis which is always seen. However, our results are based on univariate comparisons, and as such, should be viewed with some caution.
\end{abstract}




\section{Background}

Extranodal NK/T-cell lymphoma, nasal type (nasal NK/T cell lymphoma) is characterized by progressive, unrelenting ulceration, and necrosis of the nasal cavity and midline facial tissues. This subtype of lymphoma, categorized as angiocentric lymphoma in the Revised EuropeanAmerican Lymphoma (REAL) classification [1], has been renamed extranodal NK/T-cell lymphoma, nasal type in the new WHO classification of lymphoid neoplasms [2]. This type of lymphoma is rare in the United States and Europe but common in Asia [3-6]. The prognosis of Asian population as well as Central American population is not so poor as European population [7]. Phenotypically, this lymphoma is characterized by expression of NK cell marker CD56, lack of expression of surface CD3, infrequent expression of T-lineage markers other than CD2, absence of T-cell receptor rearrangement, and strong association with Epstein-Barr virus (EBV) [6,8].

Nasal NK/T cell lymphoma is an aggressive disease and has a poor prognosis. One of reasons for the poor prognosis of nasal NK/T cell lymphoma is that NK/T-cell lymphomas are refractory to conventional chemotherapy [9-11]. Doxorubicin-containing chemotherapy regimens generally appear less efficacious, either as an initial treatment or as a salvage treatment for relapsed lesions in the management of NK/T-cell lymphoma patients [10]. The ineffectiveness of chemotherapy for such lymphoma types can be partly explained by the presence of the multi-drug resistance (MDR) phenotype, which confers cellular resistance to a variety of unrelated anticancer agents [1012]. Despite accumulating experimental evidence that high levels of P-glycoproteins are commonly expressed in malignant tumor cells of various types of NK-neoplasms $[12,13]$, convincing data is very limited, largely due to the rarity of these types of lymphomas [14].

Another reason for the poor prognosis of nasal NK/T cell lymphoma is its strong tendency of widespread relapse or dissemination into distant sites. Essential steps in the process of tumor invasion and metastasis include the degradation of the extracellular matrix (ECM) and basement membrane (BM). The invasion of the BM by tumor cells is thought to be one of the critical steps in metastasis, which includes sequential multistep processes [15]. Many proteolytic enzymes degrade components of the ECM and BM $[16,17]$. Among these, the matrix metalloproteinases (MMPs) are attractive candidates as enzymes required for tumor metastasis. The MMPs contain a zinc ion at their active sites and can degrade native collagens and other ECM components $[18,19]$. The MMP family includes four types of collagenase (MMP-1, -8, -13, and -18), three types of stromelysin (MMP-3,-10, and -11), and the 72- and 92$\mathrm{kDa}$ type IV gelatinases or collagenases (MMP-2 and MMP-9). As type IV collagen is one of the integral compo- nents of BM, the uncontrolled expression of two type IV collagenases, MMP-9, is believed to play a critical role in the invasion of $\mathrm{BM}$ by tumor cells [20]. The release of MMP-9 has been associated with metastasis in a variety of model systems [21-24]. MMP-9 can be also responsible for chemoresistance of NK/T-cell lymphoma. Higher expression of MMP-9 could result in tissue necrosis due to more angiodestruction. Poor drug delivery owing to tissue necrosis might be an important contributory factor [8].

In the current study, we performed an immunohistochemical study of the expression of P-glycoprotein and MMP-9 in nasal NK/T-cell lymphoma and other types of nasal lymphomas (non-NK/T cell lymphoma) to elucidate the unique characteristics of nasal NK/T-cell lymphoma, such as its resistance of chemotherapy and strong metastatic tendency.

\section{Methods \\ Population}

A total of 45 patients with nasal lymphoma were treated in our institution between January 1980 and December 2005. The patient population consisted of 20 patients (10 men, 10 women) with nasal NK/T cell lymphoma, and 25 patients (12 men, 13 women) with nasal non-NK/T cell lymphoma (Table 1). Cases with nasal non-NK/T cell lymphoma consisted of 18 patients with diffuse large Bcell lymphoma, one with B-cell small lymphocytic lymphoma, 3 with peripheral T-cell lymphoma, unspecified, one with follicular lymphoma, adult T-cell Lymphoma, and anaplastic large cell, T-cell lymphoma according to the WHO classification system. Patients were usually followed every 2 months for the first 2 years and every 3 to 5 months subsequently. Physical and endoscopical examination were performed at every visit and CT were usually performed every 6 months. The median follow-up period of surviving patients was 94 months.

Table I: Characteristics of patients

\begin{tabular}{|c|c|c|}
\hline & NTL & non-NTL \\
\hline Patient number & 20 & 25 \\
\hline Median age (range) & $56(27-74)$ & $59(2 I-8 I)$ \\
\hline Sex (male:female) & $10: 10$ & $12: 13$ \\
\hline \multicolumn{3}{|l|}{ Stage } \\
\hline I & 14 & 14 \\
\hline$\|$ & 4 & 6 \\
\hline III, IV & 2 & 4 \\
\hline B symptoms & 14 & 2 \\
\hline Yes & 14 & 2 \\
\hline No & 6 & 23 \\
\hline \multicolumn{3}{|l|}{ EBER } \\
\hline Yes & 18 & 6 \\
\hline No & 2 & 19 \\
\hline
\end{tabular}




\section{Treatment of the primary tumor}

The radiation portal encompassed only clinically involved areas with a generous margin in most patients and prophylactic irradiation to the neck and supraclavicular lymph nodes was not usually performed. The median dose received was $40 \mathrm{~Gy}$ (range 9-74 Gy). The radiation doses were heterogeneous because the radiation was interrupted in 2 patients with nasal NK/T cell lymphoma due to deterioration of general condition and becuase in 1990 the standard radiation dose was increased from 40 Gy to 50 Gy for patients with nasal NK/T cell lymphoma.

From 1980 to 1986, radiation therapy alone was the primary treatment, although adjuvant chemotherapy was given to some patients. Since 1987, a combination of radiotherapy and chemotherapy has been the standard treatment. The main chemotherapy combinations before 1985 did not include adriamycin, e.g. COP (cyclophosphamide, vincristine, and prednisolone) or VEMP (vincristine, cyclophosphamide, methotrexate and prednisolone). These were administered after radiotherapy. Most patients from 1985 on received CHOP (cyclophosphamide, doxorubicin, vincristine, and prednisolone), VEPA (same drugs as CHOP, but doses and treatment schedule were different), or MACOP-P (methotrexate, doxorubicin, cyclophosphamide, vincristine, prednisolone, and pepleomycin) had been used before and after radiotherapy since 1989.

\section{Statistical Analysis}

All but 3 surviving patients had a minimum follow-up of 2 years and the follow-up periods of the other 3 patients were, 1, 1, and 4 months. The median follow-up of surviving patients was 94 months. Survival rates of the patients were measured using the Kaplan-Meier method. The overall survival was calculated from the date when the treatment started to the time of death or last follow-up. The distant involvement free survival was calculated from the date when the treatment started to the time of diagnosis of distant metastasis or last follow-up. Statistical significance was compared by the log rank test.

\section{Immunohistochemical Examination}

All of the biopsies were taken at the initial time of the diagnosis. Immunohistochemical staining was carried out with methods previously described [25]. All of the biopsies were taken at the initial time of the diagnosis. We used biopsy samples of 43 patients and samples of 3 patients were not evaluable because they were too tiny. Immunohistochemical staining was carried out using the avidinbiotin-peroxidase complex method.

Immunohistochemical detection was performed using the following monoclonal antibodies: antihuman MMP-9 (56-2A4, Daiichi Fine Chemical Co., Ltd., Japan)(1: 200 dilution), and MDR/P-glycoprotein antibody (C-494, Dako; 1:100 dilution). Normal mouse serum was substituted for primary antibodies as a negative control.

The specificity and selectivity of antibody of MMP-9 was proved by Fujimoto et al. and this manufacturer [26]. For MMP-9, tumors that contained at least focally moderate to strong immunoreactivity were considered positive.

To detect P-glycoprotein, we selected mouse anti-human C-494 antibody, which recognizes an internal epitope located on the C-terminal domain of the P-glycoprotein molecule, and which is encoded by two closely related genes, MDR1 and MDR3. Tumors were considered positive for P-glycoprotein expression if the neoplastic cells exhibited membrane staining greater than $10 \%$, according to a cutoff value that has been recommended in the majority of immunohistochemical studies for B-cell lymphomas [27].

\section{In situ hybridization}

RNA-DNA in situ hybridization was performed on formalin-fixed paraffin-embedded tissue sections using the biotinylated synthetic DNA probe as previously described with modifications [28]. Briefly, the biotinylated probe was an oligonucleotide DNA complimentary to EBER1 sequence that was chemically labeled with 6 biotin molecules (5'-CCCTAGCAAAACCTCTAGGGCAGC-(TAG)5BBB-(TAG)2-BBB-3'). The hybridization signal was detected by using ABC-peroxidase. The sections were then counterstained with hematoxylin, dehydrated, mounted with permount, and investigated under a light microscope.

\section{Results}

Clinically, nasal NK/T cell lymphoma had unique features characterized by destruction of the nasal cavity and midline facial tissues caused by progressive and unrelenting ulceration and necrosis of the involved tissues, as demonstrated in Fig. 1. This destructive feature of nasal NK/T cell lymphoma is very characteristic, and distinct from the other types of malignant lymphoma, which form tumors or cause swelling of the involved lymph nodes. A characteristic feature is invasion of vascular walls and, usually occlusion of lumina by lymphoid cells. The vascular occlusion is usually associated with prominent ischemic necrosis of both tumor cells and normal tissue.

Most patients (70\%) with nasal NK/T cell lymphoma had B symptoms, such as fever or unexplained loss of $10 \%$ or more of their body weight in the six months before diagnosis. In contrast, only less than $10 \%$ of patients with nasal non-NK/T cell lymphoma had B symptoms (Table 1). EBER1 transcripts were detected in 18 of 20 patients 

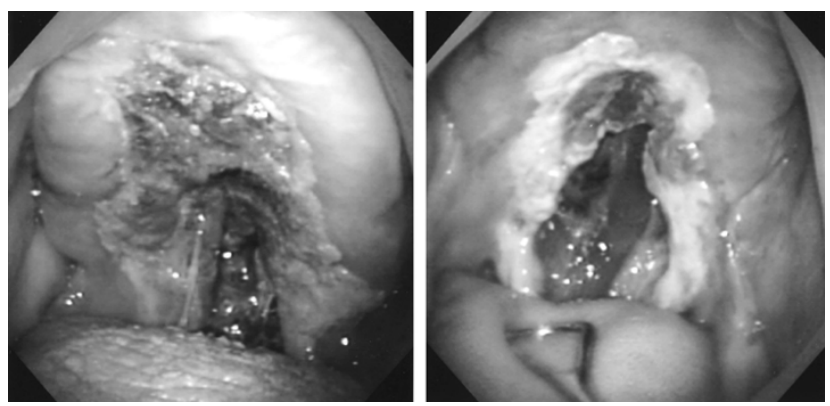

\section{Figure I}

There was a deep ulcer in the middle of the hard palate with foul-smelling discharge (left photo). After radiotherapy, the tumor disappeared and deficit of the anterior palate appeared (right photo).

with nasal NK/T cell lymphoma (Table 1), indicating strong association with Epstein-Barr virus (EBV).

Overall 5-year survival rates for patients with nasal NK/T cell lymphoma, and nasal non-NK/T cell lymphoma were $51 \%$, and $84 \%(\mathrm{p}=0.58)$, respectively (Fig. $2 \mathrm{a})$. The clinical courses were quite aggressive and nasal NK/T cell lymphoma patients have a higher incidence of widespread extranodal involvement, even though their stage was only I or II. Distant involvementfree 5-year survival rates for patients with nasal NK/T cell lymphoma, and nasal nonNK/T cell lymphoma were 53\%, and 79\% (p = 0.18), respectively (Fig. 2b). The difference is not statistically significant, however, this is most likely because of the small sample size.

Within malignant cells, patterns of P-glycoprotein immunoreactivity generally were of membrane staining, but cytoplasmic immunoreactivity was occasionally observed in some tumor cells (Fig. 3a). When a staining distribution cutoff value of greater than $10 \%$ was used to classify positive immunoreactivity, overall positivity for P-glycoprotein was observed in 10 of 19 patients with NTL and in 13 of 23 patients with non-NTL (Table 2). When the overall survival rate was compared between patients with Pglycoprotein positive and negative, there was no difference between them $(\mathrm{p}=0.88)$ (Fig. 4). The similar result was obtained, when this analysis was also done separately for T and B cell lymphomas. The 5-year survival rate for Pglycoprotein positive and negative in $\mathrm{T}$ cell lymphomas was $68 \%$ and $67 \%$. The 5 -year survival rate for P-glycoprotein positive and negative in B cell lymphomas was $85 \%$ and $71 \%$.

To identify the localization of the MMP-9 gene product, immunohistochemical staining was performed on biopsy sections of patients with NK/T cell lymphoma and non-
A

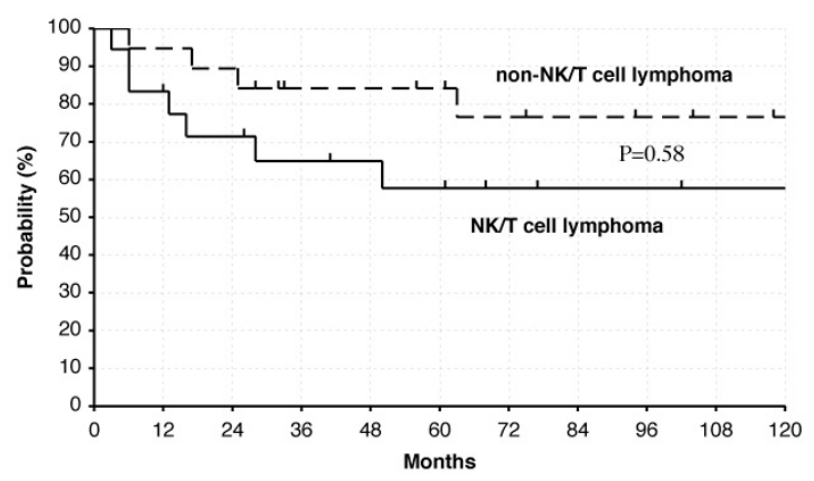

B

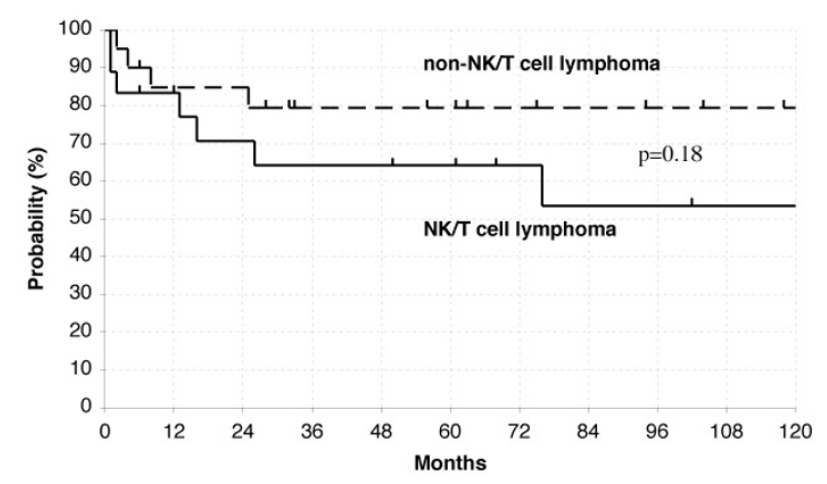

Figure 2

(a) The overall survival rates of patients of stage I or II with nasal NK/T cell lymphoma and nasal non-NK/T cell lymphoma. (b) The distant involvement free rates of patients of stage I or II with nasal NK/T cell lymphoma and nasal nonNK/T cell lymphoma.

NK/T cell lymphoma (Fig. 3b, Table 3). Sixteen of the 19 patients with nasal NK/T cell lymphoma expressed MMP9 . In contrast, only 8 of the 22 patients with nasal nonNK/T cell lymphoma expressed MMP-9. Immunohistochemically, the MMP-9 gene product was localized in lymphoma cells, macrophages, and neutrophils. All cells that were positive for MMP-9 were intensely stained, indicating that they expressed high levels of MMP-9. Cells which expressed MMP-9 existed at the invasive edge of tumor cell nests and the peripheral regions of the necrotic zone in nasal NK/T cell lymphomas. Distant involvement free 5-year survival rates were compared between patients with MMP-9 positive and negative (Fig. 5). Distant involvement free 5-year survival rates for patients with MMP-9 negative, and MMP-9 positive were 92\%, and $61 \%$, respectively. The difference was statistically significant $(\mathrm{p}=0.027)$. The similar result was obtained, when this analysis was also done separately for $\mathrm{T}$ and $\mathrm{B}$ cell lymphomas. Distant involvement free 5-year survival rates for 


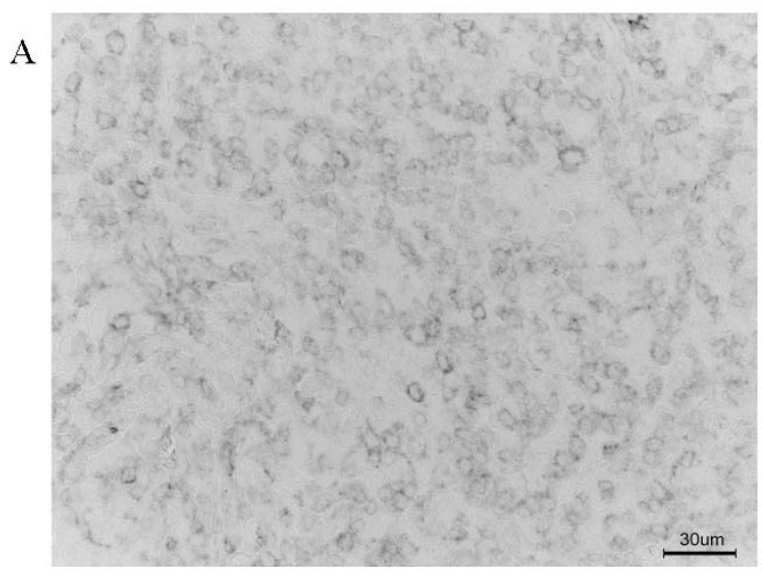

B

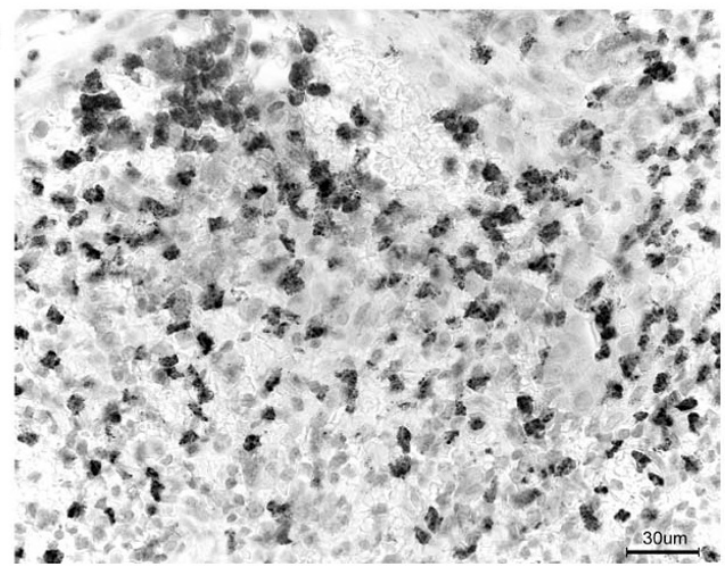

\section{Figure 3}

(a) Expression of P-glycoprotein in nasal NK/T cell lymphoma (original magnification, $\times 200$ ). (b) Expression of MMP-9 in nasal NK/T cell lymphoma (original magnification, $\times 200$ ).

patients with MMP-9 negative, and MMP-9 positive in T cell lymphomas were $89 \%$, and $57 \%$, respectively. Distant involvement free 5 -year survival rates for patients with MMP-9 negative, and MMP-9 positive in B cell lymphomas were $100 \%$, and $62 \%$, respectively.

Table 2: Expression of P-glycoprotein according to WHO classification

\begin{tabular}{lcc}
\hline & positive & negative \\
\hline NTL & 10 & 9 \\
Peripheral T cell lymphoma, unspecified & 2 & 1 \\
Anaplastic large cell, T-cell lymphoma & 0 & 1 \\
Adult T-cell Lymphoma & 1 & 0 \\
DLBCL & 8 & 8 \\
Follicular lymphoma & 1 & 0 \\
B-cell small lymphocytic lymphoma & 1 & 0 \\
\hline
\end{tabular}

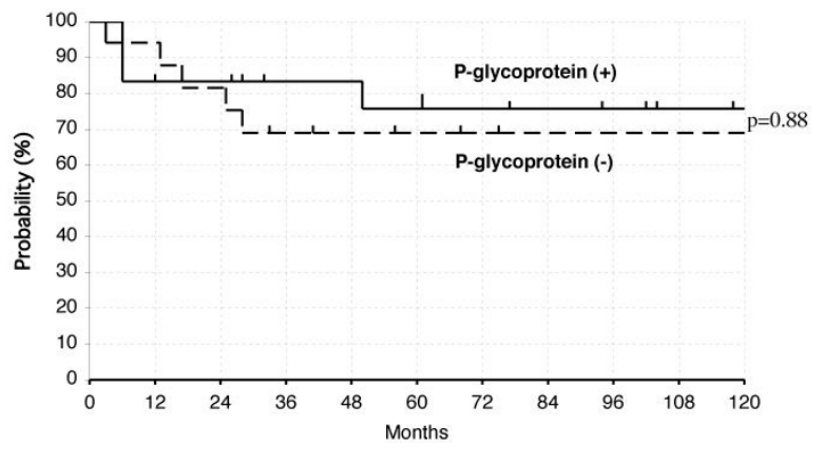

Figure 4

The overall survival rates of patients with $B$ and T-cell lymphomas of stage I or II with P-glycoprotein positive or negative. All classifications of B and T-cell lymphomas were joined together and analyzed.

\section{Discussion}

The overall outcome of nasal NK/T cell lymphoma is poor, even if diagnosed in the early stage $[9,29,30]$. One of the reasons for the poor prognosis of nasal NK/T cell lymphoma is its resistance to chemotherapy. Cheung et al. reported that of 61 patients who were administered chemotherapy, 31 showed disease progression while receiving chemotherapy, of whom 17 progressed locoregionally. They concluded that the addition of anthracycline-containing chemotherapy to radiotherapy does not appear to confer any survival benefit in stage I patients [8]. The reasons for the resistance to chemotherapy are not clear. The overexpression of MDR1 phenotype is considered one of the major determinants for the ineffectiveness of chemotherapy in nasal NK/T-cell lymphoma patients $[10,11]$. However, there was no significant difference in overall positivity for P-glycoprotein between NTL and non-NTL

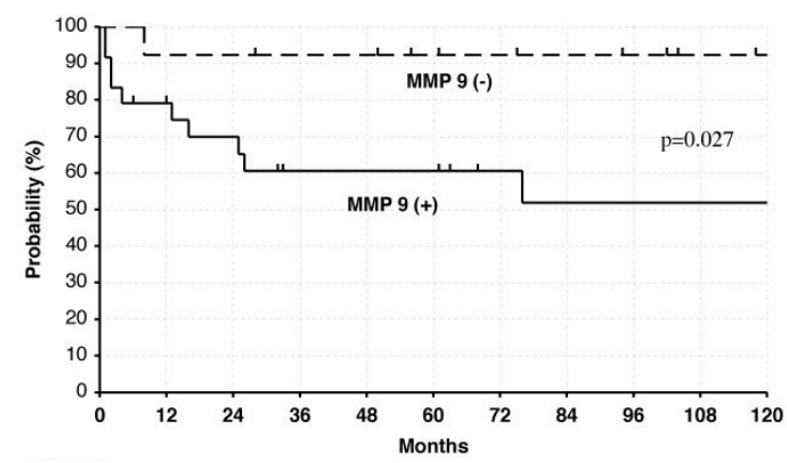

\section{Figure 5}

The distant involvement free rates of patients with $B$ and $T$ cell lymphomasof stage I or II with MMP9 positive or negative. All classifications of B and T-cell lymphomas were joined together and analyzed. 
Table 3: Expression of MMP9 according to WHO classification

\begin{tabular}{lcc}
\hline & positive & negative \\
\hline NTL & 16 & 3 \\
Peripheral T cell lymphoma, unspecified & 2 & 1 \\
Anaplastic large cell, T-cell lymphoma & 0 & 1 \\
Adult T-cell Lymphoma & 0 & 1 \\
DLBCL & 5 & 11 \\
Follicular lymphoma & 0 & 1 \\
B-cell small lymphocytic lymphoma & 1 & 0 \\
\hline
\end{tabular}

in our study (Table 2). Positive immunoreactivity for Pglycoprotein was not found to be an important prognostic factor for patients' survival (Fig. 4). Kim et al. reported similar results obtained by using the same antibody, mouse anti-human C-494 antibody on paraffin-embedded sections [14]. These results indicate that the frequent expression of MDR (P-glycoprotein-positive) phenotype may account for a certain proportion [12], but not all, of the failure of chemotherapy [31]. Necrosis is also a constant microscopical feature in nasal NK/T cell lymphoma, usually with a zonal pattern of distribution that suggests a vascular pathogenesis. Poor drug delivery owing to tissue necrosis resulting from angiodestruction by nasal NK/T cell lymphoma cells might be an important contributory factor [8].

Another reason for the poor prognosis of nasal NK/T cell lymphoma is its strong tendency to widespread relapse or to disseminate into distant sites. Common sites of distant involvement during progression of the disease were systemic lymph nodes, lung, liver, spleen, skin, and gastrointestinal tracts [32]. We found that most patients with nasal NK/T cell lymphoma expressed high levels of MMP9. Release of MMP-9 enables tumor cells to invade through basement membranes of blood vessels and lymphatics, thereby initiating metastatic spread $[16,33]$. Thus, the strong expression of MMP-9 in nasal NK/T cell lymphoma may explain its strong tendency to metastasize.

We also reported the expression of MMP9 in 158 patients with non-Hodgkin's lymphomas [34]. Almost all of the patients with nasal NK/T cell lymphoma and anaplastic large-cell lymphoma expressed MMP9. In this study, 15 of $17(88 \%)$ patients of nasal NK/T cell lymphoma expressed MMP9. Five of $8(63 \%)$ of peripheral T-cell lymphomas, unspecified expressed MMP9 and 4 of $4(100 \%)$ of peripheral T-cell lymphomas, unspecified expressed MMP9. In contrast, only a small fraction of the patients with exranodal marginal zone B-cell lymphoma of mucosa-associated lymphoid tissue type and follicular lymphomas expressed MMP9. About $50 \%$ of the diffuse large B-cell lymphomas (DLBCL) expressed MMP9. Over- all survival rates of patients who expressed MMP9 were significantly lower than those who did not.

Inhibition of the function of MMPs is being pursued for anticancer therapy. TIMPs (tissue inhibitors of metalloprotease) were first compounds to be considered for clinical development. However, the lack of effective methods of systemic gene delivery has limited the clinical utility of this approach, whereas the development of synthetic inhibitors of MMPs has been actively pursued and widely tested in clinical trials [35].

Progress in the treatment for nasal NK/T lymphomas has been slow due to the rarity of the diseases, geographic variation, relative chemoresistance, and lack of randomized trials. There is no consensus about o ptimal therapy and recommendations are based on anecdotal reports, small series, and phase II trials. There is general agreement that results with CHOP alone are so poor in adults with most peripheral T/NK cell lymphomas [36]. So, the combined radiotherapy and chemotherapy was used [37]. We previously reported 65 patients with mature T/NK-cell lymphomas treated with radiotherapy between 1983 and 2002 to analyze the influence of radiotherapy doses and chemotherapy doses and clinical parameters on in-field disease control in order to assess the optimal radiation doses for treatment of mature T/NK-cell lymphomas [38]. There were no significant differences in radiosensitivity among subtypes of mature T/NK-cell lymphomas, at least between nasal NK/T cell lymphoma and peripheral T-cell lymphomas, unspecified. Radiation doses of $50 \mathrm{~Gy}$ or more may be required to obtain in-field control of mature T/NK-cell lymphomas [38].

\section{Conclusion}

In conclusion, positive immunoreactivity for P-glycoprotein was not an independent prognostic factor in nasal NK/T-cell lymphomas. Although the role of strong MMP9 expression in the spread of nasal NK/T cell lymphoma has yet to be definitely established, our findings demonstrated that MMP-9 may be related to a strong tendency to metastasize and the locally destructive nature of nasal NK/ $\mathrm{T}$ cell lymphoma. However, our results are based on univariate comparisons, and as such, should be viewed with some caution.

\section{Competing interests}

The author(s) declare that they have no competing interests.

\section{Authors' contributions}

KS and MS carried out immunohistochemical examinations and drafted the manuscript. $\mathrm{MH}$ and TH (Tetsuo $\mathrm{HiMi}$ ) treated patients and statistical analyses. MO, HA, and TH (Takashi Hasegawa) performed the histological 
diagnosis and in situ hybridization. All authors read and approved the final abstract.

\section{References}

I. Harris NL, Jaffe ES, Stein H, Banks PM, Chan JK, Cleary ML, Delsol G, De Wolf-Peeters C, Falini B, Gatter KC: A revised EuropeanAmerican classification of lymphoid neoplasms: a proposal from the International Lymphoma Study Group.[comment]. Blood |994, 84(5): | 361-1392.

2. Harris NL, Jaffe ES, Diebold J, Flandrin G, Muller-Hermelink HK, Vardiman J, Lister TA, Bloomfield CD: World Health Organization classification of neoplastic diseases of the hematopoietic and lymphoid tissues: report of the Clinical Advisory Committee meeting-Airlie House, Virginia, November 1997.[comment]. Journal of Clinical Oncology 1999, I 7( I 2):3835-3849.

3. Aozasa K, Ohsawa M, Tajima K, Sasaki R, Maeda H, Matsunaga T, Friedmann I: Nation-wide study of lethal mid-line granuloma in Japan: frequencies of wegener's granulomatosis, polymorphic reticulosis, malignant lymphoma and other related conditions. International Journal of Cancer 1989, 44(I):63-66.

4. Ferry JA, Sklar J, Zukerberg LR, Harris NL: Nasal Iymphoma. A clinicopathologic study with immunophenotypic and genotypic analysis. American Journal of Surgical Pathology 1991, I 5(3):268-279.

5. Ho FC, Choy D, Loke SL, Kung IT, Fu KH, Liang R, Todd D, Khoo RK: Polymorphic reticulosis and conventional lymphomas of the nose and upper aerodigestive tract: a clinicopathologic study of 70 cases, and immunophenotypic studies of 16 cases. Human Pathology 1990, 2 I ( I 0): I 041-1050.

6. Jaffe ES, Chan JK, Su IJ, Frizzera G, Mori S, Feller AC, Ho FC: Report of the Workshop on Nasal and Related Extranodal Angiocentric T/Natural Killer Cell Lymphomas. Definitions, differential diagnosis, and epidemiology. American Journal of Surgical Pathology 1996, 20(I): I03-III.

7. Pagano L, Gallamini A, Trape G, Fianchi L, Mattei D, Todeschini G, Spadea A, Cinieri S, lannitto E, Martelli M, Nosari A, Bona ED, Tosti ME, Petti MC, Falcucci P, Montanaro M, Pulsoni A, Larocca LM, Leone G, Intergruppo Italiano L: NK/T-cell lymphomas 'nasal type': an Italian multicentric retrospective survey. Ann Oncol 2006, I 7(5):794-800.

8. Cheung MM, Chan JK, Lau WH, Ngan RK, Foo WW: Early stage nasal NK/T-cell lymphoma: clinical outcome, prognostic factors, and the effect of treatment modality. International Journal of Radiation Oncology, Biology, Physics 2002, 54(I): I82-190.

9. Cheung MM, Chan JK, Lau WH, Foo W, Chan PT, Ng CS, Ngan RK: Primary non-Hodgkin's lymphoma of the nose and nasopharynx: clinical features, tumor immunophenotype, and treatment outcome in II3 patients. J Clin Oncol 1998, I 6(I):70-77.

10. Kim GE, Lee SW, Chang SK, Park HC, Pyo HR, Kim JH, Moon SR, Lee HS, Choi EC, Kim KM: Combined chemotherapy and radiation versus radiation alone in the management of localized angiocentric lymphoma of the head and neck. Radiother Oncol 200I, 6 I (3):26I-269.

II. Ribrag V, Ell Hajj M, Janot F, Girinsky T, Domenge C, Schwaab G, Fenaux $P$, Bosq J: Early locoregional high-dose radiotherapy is associated with long-term disease control in localized primary angiocentric lymphoma of the nose and nasopharynx. Leukemia 200।, I 5(7): I I23-II 26.

12. Yamaguchi M, Kita K, Miwa H, Nishii K, Oka K, Ohno T, Shirakawa S, Fukumoto M: Frequent expression of P-glycoprotein/MDR I by nasal T-cell lymphoma cells. Cancer 1995, 76(I I):235I-2356

13. Egashira M, Kawamata N, Sugimoto K, Kaneko T, Oshimi K: P-glycoprotein expression on normal and abnormally expanded natural killer cells and inhibition of P-glycoprotein function by cyclosporin A and its analogue, PSC833. Blood 1999, 93(2):599-606.

14. Kim GE, Yang WI, Lee SW, Rha SY, Chung HC, Kim JH, Cho JH, Suh CO, Yoo NC, Roh JK, Hahn JS: Lack of correlation between P. glycoprotein and chemotherapy resistance in nasal NK/Tcell lymphomas. Leuk Lymphoma 2004, 45(9): I857- I864.

15. Liotta LA, Rao CN, Wewer UM: Biochemical interactions of tumor cells with the basement membrane. Annual Review of Biochemistry 1986, 55:1037-1057.
16. Moscatelli D, Rifkin DB: Membrane and matrix localization of proteinases: a common theme in tumor cell invasion and angiogenesis. Biochimica et Biophysica Acta 1988, 948(I):67-85.

17. Pauli BU, Schwartz DE, Thonar EJ, Kuettner KE: Tumor invasion and host extracellular matrix. Cancer Metastasis Reviews 1983, 2(2): $129-152$.

18. Liotta LA, Steeg PS, Stetler-Stevenson WG: Cancer metastasis and angiogenesis: an imbalance of positive and negative regulation. Cell |99I, 64(2):327-336.

19. Matrisian LM: Metalloproteinases and their inhibitors in matrix remodeling. Trends in Genetics 1990, 6(4): $121-125$.

20. Liotta LA: Tumor invasion and metastases--role of the extracellular matrix: Rhoads Memorial Award lecture. Cancer Research 1986, 46(I): I-7.

21. Bernhard EJ, Gruber SB, Muschel RJ: Direct evidence linking expression of matrix metalloproteinase 9 (92-kDa gelatinase/collagenase) to the metastatic phenotype in transformed rat embryo cells. Proceedings of the National Academy of Sciences of the United States of America 1994, 9 I ( I 0):4293-4297.

22. Hua J, Muschel RJ: Inhibition of matrix metalloproteinase 9 expression by a ribozyme blocks metastasis in a rat sarcoma model system. Cancer Research 1996, 56(22):5279-5284.

23. Sehgal G, Hua J, Bernhard EJ, Sehgal I, Thompson TC, Muschel RJ: Requirement for matrix metalloproteinase-9 (gelatinase B) expression in metastasis by murine prostate carcinoma. American Journal of Pathology 1998, I 52(2):591-596.

24. Sugiura Y, Shimada H, Seeger RC, Laug WE, DeClerck YA: Matrix metalloproteinases- 2 and $\mathbf{- 9}$ are expressed in human neuroblastoma: contribution of stromal cells to their production and correlation with metastasis. Cancer Research 1998, 58(I 0):2209-2216.

25. Sakata K, Matsumoto $Y$, Tauchi H, Satoh M, Oouchi A, Nagakura H, Koito K, Hosoi Y, Suzuki N, Komatsu K, Hareyama M: Expression of genes involved in repair of DNA double-strand breaks in normal and tumor tissues. International Journal of Radiation Oncology, Biology, Physics 2001, 49(1):161-167.

26. Fujimoto N, Mouri N, Iwata K, Ohuchi E, Okada Y, Hayakawa T: A one-step sandwich enzyme immunoassay for human matrix metalloproteinase 2 (72-kDa gelatinase/type IV collagenase) using monoclonal antibodies. Clinica Chimica Acta 1993, 22 I ( I2):91-I03.

27. Yuen AR, Sikic BI: Multidrug resistance in lymphomas. J Clin Oncol 1994, I 2( I I):2453-2459.

28. Montone KT, Brigati DJ: In situ molecular pathology: instrumentation, oligonucleotides, and viral nucleic acid detection. J Histotechnol 1994, I 7:195-201.

29. Chim CS, Ooi GC, Shek TW, Liang R, Kwong YL: Lethal midline granuloma revisited: nasal T/Natural-killer cell lymphoma. Journal of Clinical Oncology 1999, I 7(4): I322-I325.

30. Kwong YL, Chan AC, Liang R, Chiang AK, Chim CS, Chan TK, Todd D, Ho FC: CD56+ NK lymphomas: clinicopathological features and prognosis. British Journal of Haematology 1997 , 97(4):82I-829.

31. Su IJ, Chen JY: The role of Epstein-Barr virus in lymphoid malignancies. Critical Reviews in Oncology-Hematology 1997, 26(I):25-4I.

32. Harabuchi Y, Imai S, Wakashima J, Hirao M, Kataura A, Osato T, Kon $\mathrm{S}$ : Nasal T-cell lymphoma causally associated with EpsteinBarr virus: clinicopathologic, phenotypic, and genotypic studies. Cancer 1996, 77(1 0):2137-2149.

33. Hart IR, Goode NT, Wilson RE: Molecular aspects of the metastatic cascade. Biochimica et Biophysica Acta I989, 989(I):65-84.

34. Sakata K, Satoh M, Someya M, Asanuma H, Nagakura H, Oouchi A, Nakata K, Kogawa K, Koito K, Hareyama M, Himi T: Expression of matrix metalloproteinase 9 is a prognostic factor in patients with non-Hodgkin lymphoma. Cancer 2004, I 00(2):356-365.

35. Hidalgo M, Eckhardt SG: Development of matrix metalloproteinase inhibitors in cancer therapy. Journal of the National Cancer Institute 2001, 93(3): 178-193.

36. Greer JP: Therapy of peripheral T/NK neoplasms. Hematology 2006:331-337.

37. Shikama N, Ikeda H, Nakamura S, Oguchi M, Isobe K, Hirota S, Hasegawa $M$, Nakamura K, Sasai K, Hayabuchi N: Localized aggressive non-Hodgkin's lymphoma of the nasal cavity: a survey by the Japan Lymphoma Radiation Therapy Group. Int J Radiat Oncol Biol Phys 200I, 5 I(5): I 228-I233. 
38. Sakata K, Fuwa N, Kodaira T, Aratani K, Ikeda H, Takagi M, Nishio M, Satoh M, Nakamura S, Satoh H, Hareyama M: Analyses of doseresponse in radiotherapy for patients with mature T/NK-cell lymphomas according to the WHO classification. Radiother Oncol 2006, 79(2):179-184.

\section{Pre-publication history}

The pre-publication history for this paper can be accessed here:

http://www.biomedcentral.com/1471-2407/7/229/pre pub

Publish with Bio Med Central and every scientist can read your work free of charge

"BioMed Central will be the most significant development for disseminating the results of biomedical research in our lifetime. " Sir Paul Nurse, Cancer Research UK

Your research papers will be:

- available free of charge to the entire biomedical community

- peer reviewed and published immediately upon acceptance

- cited in PubMed and archived on PubMed Central

- yours - you keep the copyright

Submit your manuscript here:

http://www.biomedcentral.com/info/publishing_adv.asp 